Article

\title{
Omnichannel Customer Experience and Management: An Integrative Review and Research Agenda
}

\author{
Carmen Gerea *, Fernanda Gonzalez-Lopez and Valeria Herskovic (D)
}

Department of Computer Science, Pontificia Universidad Católica de Chile, Santiago, Chile; fgonlop@uc.cl (F.G.-L.); vherskov@ing.puc.cl (V.H.)

* Correspondence: cgerea@uc.cl

check for

updates

Citation: Gerea, C.; Gonzalez-Lopez, F.; Herskovic, V. Omnichannel Customer Experience and Management: An Integrative Review and Research Agenda. Sustainability 2021, 13, 2824. https://doi.org/ $10.3390 /$ su13052824

Received: 10 January 2021

Accepted: 25 February 2021

Published: 5 March 2021

Publisher's Note: MDPI stays neutral with regard to jurisdictional claims in published maps and institutional affiliations.

Copyright: (c) 2021 by the authors. Licensee MDPI, Basel, Switzerland. This article is an open access article distributed under the terms and conditions of the Creative Commons Attribution (CC BY) license (https:// creativecommons.org/licenses/by/ $4.0 /)$.

\begin{abstract}
In a highly competitive landscape, adopting an omnichannel approach might lead to a market advantage in terms of acquiring and retaining customers, as well as a means to ensure business sustainability. Omnichannel organizations situate the customer at the core of their interaction. However, research on omnichannel customer experience (CX) is still fragmented. In this paper, by adopting an integrative approach, we aim to articulate the empirical evidence around omnichannel CX and its management. Moreover, we show how research around omnichannel CX emerged from different theoretical perspectives and disciplines such as marketing, sociology and computer science. Towards this goal, we conducted a systematic literature review-with in depth analysis of 50 papers-and identified that omnichannel CX literature has engaged a number of research streams from various theoretical perspectives. Based on the research gaps, we propose an agenda for future research including topics such as (1) understanding the customer lifecycle in an omnichannel context; (2) integrating new touchpoints and channels; (3) predicting the omnichannel customer behavior; and (4) approaching omnichannel CX in service-based organizations. We conclude that adopting an omnichannel CX management approach requires the entire organization to be customercentric while articulating interdisciplinary teams. Available studies on omnichannel CX provide the foundations for extending the knowledge on this topic and developing tools for practitioners to use in the omnichannel management assessment, operationalization, and measurement.
\end{abstract}

Keywords: omnichannel; customer experience; retailing; systematic literature review; integrative research

\section{Introduction}

Technology has been transforming consumer behavior and reshaping the relationship between humans and organizations. Most industries have been highly affected by this digitalization and have had to adapt or transform their business models [1]. New players emerged, many of them being purely digital-e.g., Google, Amazon, Facebook, and Applebecoming such a strong reference for consumers that some have transitioned to physical retail (e.g., Amazon Books, Amazon Go). In the context of this continuously evolving business landscape, many traditional retailers and service-based companies have transitioned to omnichannel management in order to respond to a highly competitive market and to better serve their customers. At a high level, being an omnichannel organization means situating the customer at the core of the company interaction through channel integration, consistency, and a seamless customer experience [2]. For store-based retailers, omnichannel has opened the possibility to improve synergy between channels and touchpoints in order to increase store sales and potentially avoid the death of physical stores [3].

From a historical retrospective of the evolution of retailing and digital business, Huuhka et al. [4] identified three waves for describing the evolution of the omnichannel phenomenon. In the first wave (mid-1990s) retailers launched the very first online channels that were characterized by being technology-driven, managed in silos, and not integrated with traditional channels. During the second wave (around 2005 to 2014) the need for 
multichannel integration emerged. Retailers started to focus their strategies on consumer needs and understand that customers had to shop in the channel of their choice. Finally, the third wave (around 2015 up until today) sees the rise of omnichannel retailing as a response to a change in people's shopping behavior. At this stage, the integration between different channels is higher and each channel becomes a communication touchpoint between the consumer and the brand. In 2020, the Coronavirus Pandemic (COVID-19) [5] has pushed big retailers to embrace omnichannel strategies, while e-commerce platforms like Shopify enabled smaller local retailers to go online for the first time [6].

Under these circumstances, over the last decade, omnichannel has been stretching the industry at different levels, revealing multiple issues for business leaders: from the management of logistics [7], to understanding customer intention to use a given channel or adopt a new technology [8], to addressing the challenges of channel integration [9], or exploring customer behavior while combining multiple channels during the purchase journey [10]. In line with these challenges, omnichannel has captured the attention of numerous researchers, and special issues dedicated to omnichannel have been published (e.g., [2,11]). Literature reviews on the subject call for research on a wide diversity of themes as customer relationship management dynamics in an omnichannel retailing environment [12].

The present work focuses on a key aspect of omnichannel management: the omnichannel customer experience. Customer experience (CX) as a holistic concept has been challenged from different perspectives and current literature does not agree on a definition $[13,14]$. In our work, we use the definition proposed by Lemon and Verhoef [15] that see CX as a "multidimensional construct focusing on a customer's cognitive, emotional, behavioral, sensorial, and social responses to a firm's offerings during the customer's entire purchase journey". Since omnichannel organizations are expected to provide a seamless brand experience, the resulting CX is of paramount relevance. New interaction possibilities by adding channels, touchpoints and new technologies certainly complexify the CX. Moreover, recent research has addressed the concept of sustainable customer experience as a process. Even if current literature does not agree on who is responsible for sustainable development assumptions-producers or customers-customers seem to be at the center of this process [16]. In line with this, an omnichannel approach to CX will contribute to achieve a sustainable and competitive channel operation [17].

The wide breadth of channels, touchpoints and technologies involved on omnichannel organizations, combined with the growing interest on the impact of these new interactions on human behavior, has led to a fragmentation of research obscuring a holistic perspective of the CX aspects of omnichannel literature. This fragmentation is to be expected when the topic is new and researchers must approach it from an exploratory perspective. Nevertheless, as more research is published and the topic itself gains maturity, there is a greater need to consolidate existing knowledge. We believe that knowledge from the CX perspective is of high importance for better understanding and improving the implementation of the third-wave omnichannel phenomenon. The present work aims to integrate an important diversity of research streams on omnichannel $C X$ and its management via a systematic literature review following Kitchenham and Brereton [18].

This research aims to accomplish three main goals. First, our study aims at summarizing and synthesizing research regarding omnichannel CX and its management. Building on existing studies and knowledge in order to create new knowledge is fundamental in all academic research [19]. Despite several literature reviews being published on topics related to omnichannel, this is the first one that addresses the topic of omnichannel CX. Second, our work has the goal of understanding how the omnichannel CX body of knowledge emerged: i.e., which disciplines contributions came from, which authors contributed to the research field, in what countries they did the research, and which methods they used to understand this challenging topic. Third, we aim to propose a research agenda and provide directions based on the gaps we identified. This step is key for direct future research in this field. Altogether, the present work provides a contribution to the research community by (1) integrating current knowledge on omnichannel CX, (2) identifying major research 
streams, and (3) identifying research gaps that could be addressed in the future by the scientific and practitioner communities.

\section{Research Approach}

Systematic literature review (SLR) studies are an established research method designed to provide an overview of a research area by gathering, classifying and synthesizing the literature on a specific topic [18]. SLR studies have been conducted in several areas of knowledge, e.g., management [20], marketing [13], information systems [21], and computer science [18]. A key purpose of a SLR is to explicitly and transparently cover a wide body of knowledge in order to identify what we know and what we do not know about a question or a specific topic [20].

The SLR reported in this paper was undertaken based on guidelines provided by Kitchenham and Brereton [18]. First, we did a scan of literature reviews on the omnichannel topic looking into the analyzed topics and the used methodology. As Snyder [19] recommends, this initial step is fundamental in order to assess that a new SLR is making a contribution to the field. We identified several literature reviews on omnichannel-related topics that we briefly summarize in Table 1 , yet none of them addressed the CX aspect of the omnichannel phenomenon. For instance, Hossain et al. [22] identified the dimensions of multichannel integration quality; Hübner et al. [7] covered distribution systems in omnichannel retailing, while Picek et al. [23] addressed omnichannel contact centers. Analyzing the methodological perspective of these works, we identify that some of them are more similar to what Paré et al. [21] call a "structured narrative review" (meaning they review what has ben written on a specific topic without being systematic-without explaining in details how the review process has been conducted): [7,23,24]. More recently, Cai et al. [25] have used Citation Network Analysis (CNA) to present a state-of-the-art development of omnichannel management.

Table 1. Systematic reviews on omnichannel management.

\begin{tabular}{llll}
\hline \multicolumn{1}{c}{ Authors } & \multicolumn{1}{c}{ Scope } & \multicolumn{1}{c}{ Timeframe } & \multicolumn{1}{c}{ Analysis Methodology } \\
\hline Akter et al., 2019 [26] & $\begin{array}{l}\text { Dimensions of omnichannel service quality } \\
\text { State-of-the-art development of omnichannel } \\
\text { Cai et al., 2020 [25] }\end{array}$ & 2006-2016 & Thematic analysis \\
Hossain et al., 2019 [22] & Dimensions of multichannel integration quality & 2005-2019 & Citation Network Analysis \\
$\begin{array}{l}\text { Hübner et al., 2016 [7] } \\
\text { Lehrer and Jung, 2016 [27] }\end{array}$ & $\begin{array}{l}\text { Distribution systems in omnichannel retailing } \\
\text { João and Pastore, 2019 [28] }\end{array}$ & ND & Thematic analysis \\
Picek et al., 2018 [23] & $\begin{array}{l}\text { Omn the academic activity on omnichannel } \\
\text { Omnichnel contact center }\end{array}$ & 2002-2015 & ND \\
Popa et al., 2019 [24] & $\begin{array}{l}\text { Omnichannel retailing differences and } \\
\text { preferences among consumer generations }\end{array}$ & ND & Quantitative content analysis \\
This paper & $\begin{array}{l}\text { Omnichannel customer experience dimensions } \\
\text { and the related management factors }\end{array}$ & 2008-2020 & Thematic analysis \\
\hline
\end{tabular}

Note: ND = not determined.

Our approach to conduct this review differs from the previously described works in both focus topic and methodological perspective. In terms of topic, we focused on the CX aspects of omnichannel management. In terms of methodological differences we can highlight three aspects. First, we opted for a systematic approach which is fundamental as we aimed to conduct mapping and scoping research. Second, our work adopted a content-oriented perspective in contrast to other perspectives such as CNA, for instance. Third, we position our work as an integrative approach since we are aiming to bring an overview of a body of knowledge, combining perspectives and insights [19] from different theoretical lenses. 


\section{SLR Protocol}

A systematic literature review usually starts with general questions as they aim to give a broad perspective on a given subject. Our main purpose was to understand the state of the omnichannel CX research field from a general perspective. This is how the initial research question emerged:

RQ1. What is the general state of the omnichannel CX research field?

The second research question is an extension of the first one, with a focus on the topics that are addressed by the corpus of research on omnichannel CX:

RQ2. Which research streams on omnichannel CX have been the focus of academic research over the years?

As per the third research question, it emerged while collecting data for the second research question when we noticed that the variety of research streams on omnichannel CX came from a variety of theoretical perspectives. Acknowledging this allows a better understanding of the research streams and how they relate to one another and complement each other. We deem this aspect of key importance for advancing the field, and thus decided to add the following research question to our study:

RQ3. What are the theoretical perspectives adopted in current literature to address omnichannel CX?

In order to address the previous questions, we defined the following search strings: omnichannel AND experience; "omni-channel" AND experience. We applied these search strings to the following set of digital databases: ACM Digital Library, IEEEXplore, ProQuest Central, ScienceDirect, Scopus, SpringerLink, and Web of Science. These databases are highly popular both in management and computer science disciplines.

The search was conducted manually in each database. The first author retrieved a total of 1657 search results. These papers were then exported to a reference managing platform, specifically to a Mendeley library. To select papers, inclusion and exclusion criteria were defined and then applied (Figure 1, Table 2).

Table 2. Inclusion and exclusion criteria.

\begin{tabular}{|c|c|}
\hline Inclusion Criteria & Exclusion Criteria \\
\hline $\begin{array}{l}\text { 1. The paper is written in English. } \\
\text { 2. The paper is available in an electronic format. } \\
\text { 3. The paper theme is explicitly or implicitly related to } \\
\text { customer experience in an omnichannel context. } \\
\text { 4. The paper is a scholar peer-reviewed paper published } \\
\text { in a journal or conference proceedings. } \\
\text { 5. The paper presents an empirical research. }\end{array}$ & $\begin{array}{l}\text { 1. The paper is not written in English. } \\
\text { 2. The paper is not available in an electronic format. } \\
\text { 3. The paper is not peer-reviewed. } \\
\text { 4. The paper is an editor's introduction, opinion paper or final } \\
\text { article in a journal or proceedings. } \\
\text { 5. The paper is a systematic mapping study or literature review. } \\
\text { 6. The paper is not related to customer experience in an } \\
\text { omnichannel context. }\end{array}$ \\
\hline
\end{tabular}

Altogether, the included papers corresponded to peer-reviewed english-written primary studies published from 2008 to May 2020 that referred to the omnichannel and CX concepts and have an empirical component. We voluntarily opted to include all publications disregarding the prestige of the source, privileging the paper's contribution to the topic. To ensure quality of the selected papers, we discarded those that do not provide empirical validation. After removing duplicates, and publications unrelated to the topic-meaning overlapping in terms of vocabulary but representing different conceptswe conducted a first screen of the 1657 papers based on title and abstract in order to include those that were contributing to respond to the research questions. During this step, 164 primary studies were shortlisted by the first author.

A second screening process was conducted by the first two researchers based on a full-text review of the works, which then resulted in narrowing the search to 80 studies. Those 80 papers were then submitted to debate between the two researchers. This iterative process resulted in 50 peer-reviewed publications determined suitable for in-depth analysis: our research corpus (Appendix A). 


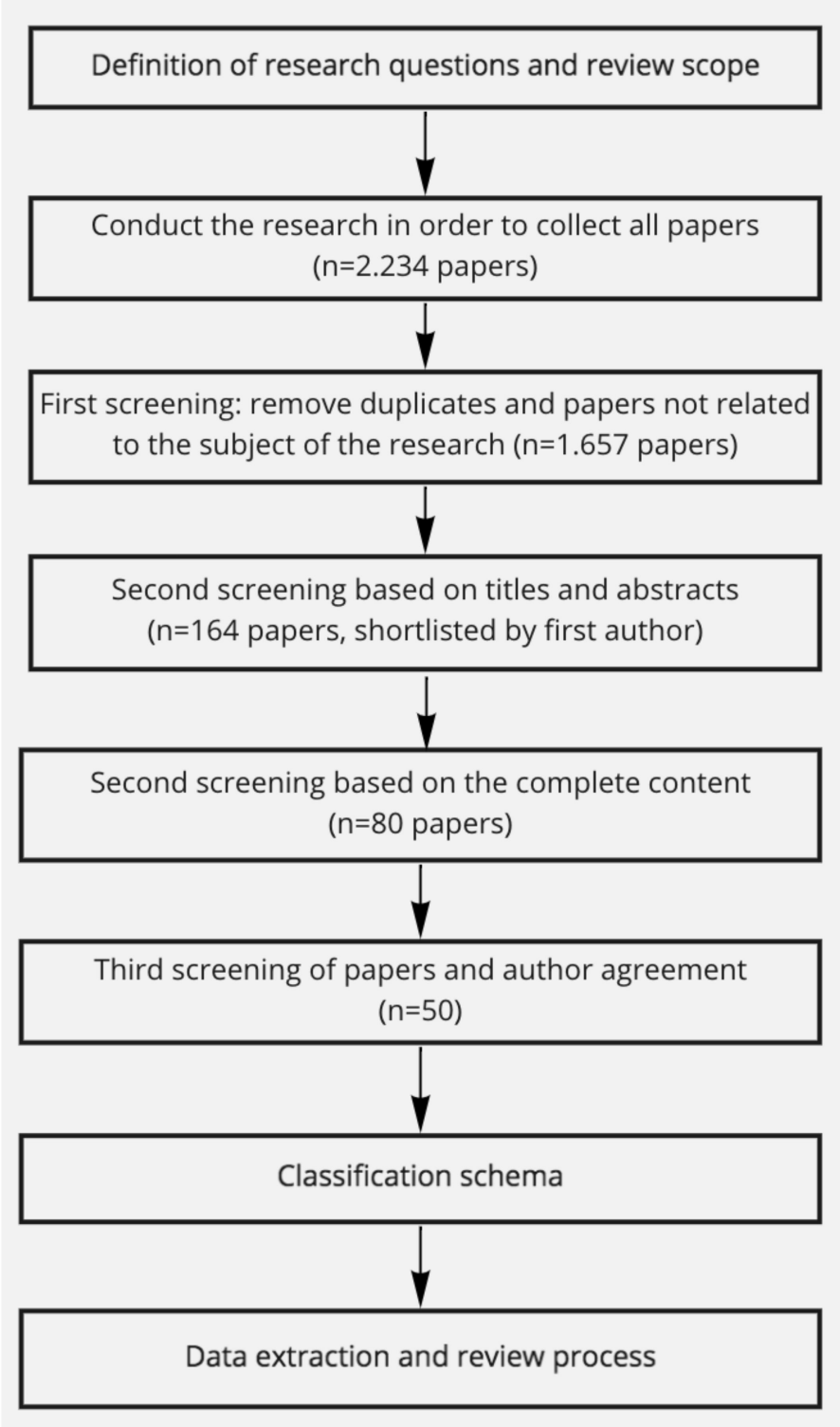

Figure 1. Systematic literature review process.

A spreadsheet was then used in order to extract the data for the classification schema based on the following criteria: title, periodical, abstract, year, authors, affiliation, discipline, theoretical perspective, research stream, B2B/B2C, research method, subjects of the study, country of the data collection, longitudinal or cross-sectional study, touchpoints considered in the study. When the study involved industrial applications or case studies, we also extracted the industries these came from. Some data were directly extracted from the content of the papers (e.g., year of publication, authors, affiliation, research method used, etc.), while other data extraction required further work (e.g., research streams and theoretical perspectives). For the latter case, we applied thematic analysis based on the guide proposed by Braun and Clarke [29], a six-step process that includes: (1) familiarizing with data, (2) generating initial codes, (3) searching for themes, (4) reviewing the themes, (5) defining and naming themes, and (6) producing the report.

The analysis of the data was conducted in three stages. First, we undertook a descriptive review of the papers. As Paré et al. contend [21], a descriptive review considers each included study as a unit of analysis and aims to "collect, codify, and analyze numeric data that reflect the frequency of the topics, authors, or methods found in the extant literature". The second stage focused on the research streams found in the analyzed papers. Finally, 
the third stage focused on the theoretical perspectives from which the selected papers were developed. Based on the previously described analysis, we provide an overview of the omnichannel customer experience research field, as well as a proposal of a future research agenda.

\section{Findings}

In the following section, we present the findings from our literature review. These results are presented according to the research questions they answer. First, we provide an overview of the omnichannel CX research field (see RQ1). Following this overview, we present the major research streams we identified (see RQ2) and, finally, the theoretical perspectives they emerged from (see RQ3). Figure 2 highlights an overview of these findings.

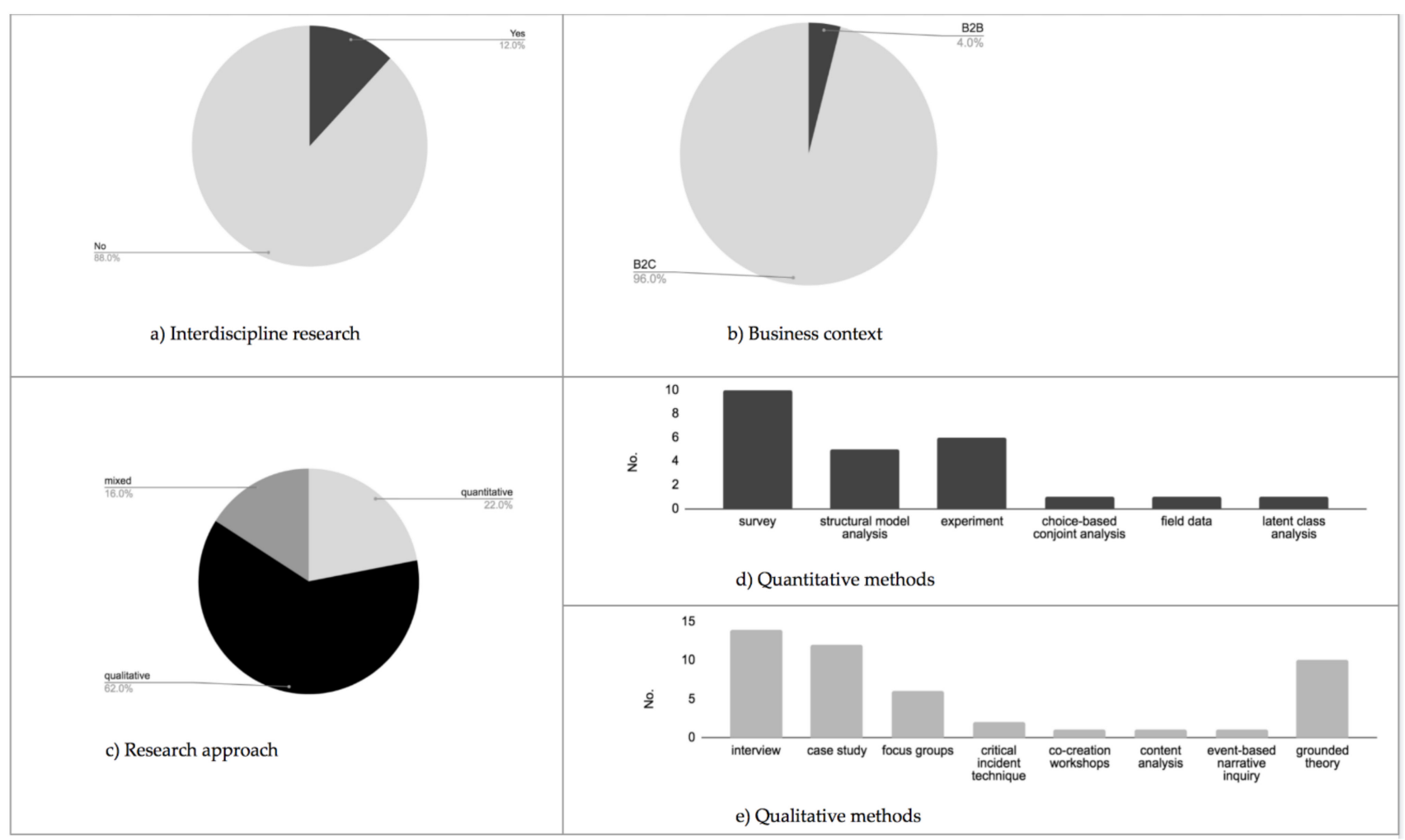

Figure 2. Overview of the research field.

\subsection{What Is the General State of the Omnichannel CX Research Field?}

In this section we briefly characterize the 50 selected papers of the research corpus. We characterize the papers in terms of the research disciplines they cover, the countries in which the research was conducted in, the business context (B2B/B2C), the research methodologies that have been used, the subjects of the studies, as well as the touchpoints covered. This characterization provides a sort of contextual information about the papers we discuss.

The selected papers mostly correspond to journal articles $(82 \%, 41 / 50)$, while conference proceedings represent the rest of our corpus. The papers came from several disciplines, which we coded based on the Web of Science classification, as shown in Figure 2. Most of the works were situated in the business administration field $(76 \%, 38 / 50)$. The remaining works came from science and technology-mainly computer science- $(12 \%, 6 / 12)$, or from interdisciplinary research between business and computing $(12 \%, 6 / 12)$. We found the selected papers were authored by 159 different authors and published in 36 different journals and conference proceedings.

In our corpus, $28 \%(14 / 50)$ of the included papers report research run in multiple countries, while the remaining $72 \%(36 / 50)$ present studies executed in a single country, 
Spain and China being the countries with the highest number of studies: 8 each one of them, followed by UK (7 studies), and Germany and US (6 studies). This count per country includes studies in multiple countries. Only one publication came from Latinamerica.

Most of the selected studies are related to a business-to-consumer (B2C) case $(96 \%$, $48 / 50)$, while only $4 \%(2 / 50$ present research in a business-to-business (B2B) context. These two papers discuss elements of an omnichannel approach for a B2B firm. First, Wang et al. [30] found that industrial brand equity has several dimensions, one of them being omnichannel advantage in communication. Second, Hossain et al. [22] show that integration quality in omnichannel marketing is a hierarchical construct including four primary dimensions and ten sub-dimensions.

Most of the selected papers draw from the retail omnichannel $(76 \%, 38 / 50)$, which is consistent with the fact that omnichannel approach was adopted in retailing [4] before other industries. Research on omnichannel CX in service-based organizations represents only $28 \%(14 / 50)$ of the included papers. Four publications focus on banking, insurance and other financial services [22,31-33]. Two papers explore tourism, travel and airline industries [34,35], while others focus on education [36] or catering [9]. Only $4 \%(2 / 50)$ of the papers came from the industrial and manufacturing sector, which is related to the B2B context we mentioned previously.

Qualitative approaches were adopted in $46 \%(23 / 50)$ of the selected papers, followed by mixed methods $(34 \%, 17 / 50)$, and quantitative research $(20 \%, 10 / 50)$. Among quantitative methods, survey, structural model analysis, and experiment were the most frequent ones; while interviews, case studies, and focus groups were the most common as a qualitative approach. The entire corpus of publications presents cross-sectional research, while there is no reported longitudinal research.

Nearly all authors considered customers their main subject of study, with $76 \%(38 / 50)$ focusing only on customers and $12 \%(6 / 50)$ involving customers and practitioners in their research. The rest $(12 \%, 6 / 50)$ involved only practitioners.

Most of the selected papers present a study involving a physical store touchpoint $(68 \%, 34 / 50)$, followed by the website $(58 \%, 29 / 50)$, and a mobile app $(40 \%, 20 / 50)$. Only $22 \%(11 / 50)$ of the mapped research examines social media and even a lower selection investigates highly digital touchpoints as email $(2 \%, 4 / 50)$, search engines $(8 \%, 4 / 50)$ or comparison websites $(8 \%, 4 / 50)$. An even lower number of papers $(2 \%, 1 / 50)$ provides evidence on the importance of call center CX.

In particular, from a total of 133 mapped touchpoints, we identified that only a very small portion $(6 \%, 7 / 133)$ represent a peer-to-peer touchpoint, while the rest of $(94 \%$, $126 / 133)$ are consumer-brand touchpoints.

\subsection{Which Research Streams on Omnichannel CX Have Been the Focus of Academic Research over the Years?}

In our endeavor to synthesize the empirical evidence, we mapped several major streams of research around omnichannel CX and its management. In this section we discuss these streams by highlighting important results. In the following, we present seven research streams from the most generals to the most specific ones. It is also often the case that the most general research streams were the most frequently discussed in the analyzed research corpus.

\subsubsection{Customer Behavior Stream}

The most important stream we identify is the customer behavior research that focuses mainly on understanding determinants of the purchase intention, willingness to pay or the intention to select a channel or adopt a new technology. For instance, in one of the first studies on predicting behavior based on mobile app usage, Taylor and Levin [37] found that user interest in a retail mobile app usage is a predictor for purchasing and information sharing. Moreover, Juaneda-Ayensa et al. [8] used the extended Unified Theory of Acceptance and Use of Technology (UTAUT2), personal innovativeness and perceived security in order to identify the factors that influence customer's omnichannel 
behavior, and find that the key determinants of purchase intention in the omnichannel context are personal innovativeness, effort expectancy and performance expectancy. More recently Goraya et al. [38] found that channel integration significantly impacts customers' channel preferences.

The consumer behavior stream is dominated by research on the consumer purchase journey. Nevertheless, some authors also address the post-purchase journey. Namely, Frasquet et al. [39] analyze the relationship between the purchase channel and the channel chosen for complaining and show that the customers when customers who are generally satisfied with the retail complain, they do so at stores and the unsatisfied ones tend to choose social media. Likewise, Frasquet et al. [40] found four different segments that use complaint channels differently: multichannel complainers (moderated intention to use multiple complain channels), heavy multichannel complainers (high intention to use each channel for complaining), web-focused multichannel complainers (more likely to use web to complain) and store-focused complainers (more likely to complain at the store). Recently, Miquel-Romero et al. [41] found that different combinations of situational, channel-related, and individual variables led to complaining at the store, while the channel of purchase was not determinant for the choice of the store to complain. To this end, social media allows to capture insights on customer complaints but also to recover the service by responding effectively [42].

Omnichannel behavior has also been investigated. In line with this, two key factors to foster omnichannel behavior are "(1) reducing the risk of losing the customer during customer journey by providing a unified and integrated services and customer experience and (2) encouraging the customer to proceed in the customer journey with the company by providing seamless and intuitive transitions across channels in each touch-point to match customer preferences, needs, and behavior" [43]. Moreover, confidence was found to be a key variable for omnichannel behavior [44].

\subsubsection{Customer Segmentation Literature Stream}

Another major research stream is the customer segmentation literature. In a tight relation with the previously mentioned customer behavior research stream, common patterns emerge based on the shoppers' behavior in the omnichannel purchase context.

For instance, several authors explore the webroomer or reverse showroomer pattern [35,43-45], meaning those shoppers that search for information online and then confirm the information offline. As established by Flavián et al. [10] webrooming has a positive impact on consumers' perceptions of making the right purchase and consumers' smart shopping feelings. It also improves the shopping experience [44]. As opposed to the webrooming pattern, showrooming means gathering information and examining products in physical stores and then purchasing online $[10,39]$. Research on shopper classification has led different authors to find specific behaviors trends according to the buying context of these two major segments-webroomers and showroomers. For example, the reverse showroomer type consumers were found to have more influence on the store attitude than the showroomer type consumers [45]. Furthermore, according to Goraya et al. [38] showrooming and webrooming are mediators for the cross-channel integration impact on consumer patronage intention for online stores.

Nevertheless, besides these two major patterns—webrooming and showroomingthere are nuances depending on personal (past experience for instance) or contextual factors such as the product category. In particular, it is to be expected that the same person will behave differently with a low-relationship product like grocery shopping where the purchase journey is usually shorter than in the context of purchasing a complex service like a trip. As a case illustration, Mahrous and Hassan [34] identify three segments based on the customer journey in the travel and tourism industry in the context of an emerging market: multichannel shoppers, multichannel searchers, and store-prone shoppers.

When adopting anticipated utility theory, Heurhausen et al. [46] found five timeconsistent segments - store-focused shoppers, pragmatic online shoppers, extensive online 
shoppers, multiple touchpoint shoppers, and online-to-offline shoppers-that had an important touchpoint and mobile device usage during their customer journey. Authors found that product satisfaction, journey satisfaction and customer inspiration were different for each of these segments and these three components were integrated into customer loyalty.

In the past years, a new business model has emerged, with the purely online stores extending their channels to offline stores. The online-to-offline market has been investigated by Xiao et al. [47] and three consumer segments were identified: return-sensitive shoppers, risk-sensitive shoppers, and rational shoppers, each one of these with their different patterns in terms of values, benefits and attributes they seek.

In addition to these patterns, novelty segmentations are introduced, based on valuein-use-meaning what customers seek in their interactions [32].

\subsubsection{Consumer Interaction with In-Store Technology Stream}

The consumer interaction with technology research stream mainly explores how brands enrich the $C X$ with a physical or digital service in a retail environment. For example, Ervasti et al. [48] show that previous experience with online shopping has a direct positive effect on the customer's willingness to adopt the service in the future. In the same way, Demko-Rihter and ter Halle [49] propose a way to bridge the gap between the online and in-store shopping through an online platform (website) and a mobile application. Similarly, Parise et al. [50] propose two technology-based models to support customer's need for immediate personalized assistance to leverage CX: the remote expert and the digital assistant. In this same context, consumer-owned technologies and its usage during the buying journey have also drawn the attention of researchers that investigated how consumers interact with triggers like QR codes or NFC [51]. Finally, in an attempt to conceptualize the phygital shopping experience, Belghiti et al. [52] explore two cases: a connected store and a scree-free store where clients create the phygital content.

\subsubsection{Omnichannel Management Stream}

The omnichannel management research addresses the implementation of an omnichannel system [53] as well as specific aspects of operating in an omnichannel context such as last mile fulfilment and distribution [7] or online retail returns management [54]. Moreover, Peltola et al. [43] interviewed Finish retailers that adopted an omnichannel approach to $\mathrm{CX}$ and concluded that in order to insure a good omnichannel $\mathrm{CX}$ it is fundamental to articulate the organizational culture with pricing, operations, and communications.

\subsubsection{Service Quality Stream}

In line with the omnichannel management stream, service quality has been stressed from different perspectives. For example, in an investigation on logistics service quality in omnichannel retailing, Murfield et al. [55] found that for omnichannel consumers, timeliness is a major driver of satisfaction and loyalty. This finding is fundamental for retailers who need to prioritize meeting promised delivery time.

Furthermore, research on channel integration quality shows that integration quality is a hierarchical construct [22] that affects perceived fluency across different channels [9] and customer engagement [56].

In an attempt to understand omnichannel service failures and recoveries, Rosenmayer et al. [42] used content analysis to classify Facebook comments and found that customers complained about the service with the brand disregarding the retail channels. Authors identify several failure and recovery typologies that can be used by organizations to better understand and address service quality issues.

\subsubsection{Omnichannel CX Construct Stream}

Several authors attempt to conceptualize omnichannel CX and identify the components of this high-level construct. Analyzing a survey on online shopping, KaczorowskaSpychalska [57] found availability of products, easiness of placing an order, availability 
of payment solutions and delivery forms, to be relevant for the omnichannel shopping experience. Furthermore, Komulainen and Makkonen [31] identified the key factors of the omnichannel $C X$ with banking services based on positive actual experiences, negative actual experiences, positive imaginary experiences and negative imaginary experiences. Similarly, in a case study looking to understand the improvement of the user experience (UX) in an online university enrolment process, authors concluded that channel coordination, greater availability and a wide range of channels, personalization, adaptation of channel content based on the customer journey stage, as well as the ability to choose the channel that best fits prospective students needs, are the main factors of the UX [36]. Finally, in a recently published study, omnichannel $C X$ was found to have five dimensions: connectivity, integration, consistency, flexibility and personalization [58].

\subsubsection{Outcomes of Omnichannel Approach Stream}

The adoption of an omnichannel approach has a profound impact on both customers and organizations at a retailer level and a channel level [59].

Based on a service-dominant logic, Kumar et al. [60] propose a framework for the customer engagement in service where the service experience is moderated by offeringrelated, value-related, enabler-related and market-related factors.

By segmenting customers based on their use of specific touchpoints in the customer journey and exploring different outcomes among these segments (product satisfaction, journey satisfaction, customer inspiration, customer loyalty) Herhausen et al. [46] found that these segments respond to different loyalty formation patterns.

Researchers also found evidence that online-offline channel integration would lead to a competitive advantage and channel synergies [59]. In line with these findings, Zhang et al. [61] found that consumer perceptions of channel integration-one of the components of an omnichannel approach-are positively related to consumer empowerment; while the consumer empowerment has a positive impact on both the perceived trust and satisfaction towards the retailer. Finally, these two outcomes (trust and satisfaction) are positively associated with patronage intention.

Omnichannel shopping-value was found to be caused by touchpoints shopping value [62]. Nevertheless, adding more touchpoints to existing channels does not always have a positive impact at a brand level. For instance, adding voice to an omnichannel platform was found to have the counterintuitive effect of reducing engagement with the platform mainly because of privacy concerns that this raises for the brand trust [62].

In an industrial context (B2B), omnichannel advantage in communication was found to be one of the dimensions of industrial brand equity [30].

\subsection{What Are the Theoretical Perspectives Adopted in Current Literature to Address Omnichannel CX?}

The authors of the included papers used different theoretical lenses in their research work as well as different research strategies. The diversity of the investigative perspectives explains why certain problems are approached from different angles. Many scholars suggest building bridges across theoretical perspectives and research traditions enables a deeper understanding of a research domain [13,63-65]. Most researchers (72\%) explicitly adopt a theoretical perspective, while the rest $(28 \%)$ do not explicitly mention it. In this section we will briefly mention the most used theoretical frameworks (based on the frequency) and provide examples of the selected studies for each theoretical perspective to illustrate how they approach omnichannel experience and its management. Moreover, several authors do not rely on a specific theory but rather on a research approach or point of view; in this category we include the customer-centric approach and the behavioral approach that we explain next, before presenting the theories behind the research corpus.

First, from a customer - centric approach and by adopting a case study methodology, Belghiti et al. [52] aim to explore the phygital shopping experience from the consumer's point of view in two situations: a connected store and a screen-free store where phygital content is provided by the clients. The phygital experience consists of a hybrid physical- 
interactive space where the point of sale coexists and is strengthened by digital components such as touchscreens, QR codes or NFC. In this research where findings arise based on observation, the phygital experience is shown to have several dimensions: spatial, temporal, hedonico-sensorial, social and participative. Depending on the goals the retailer has for the phygital experience, its role is expected to be different. If the goal is physical, then the store's role is to educate the customer mainly through the sales personnel. While if the goal is digital, the store's role is to innovate through technology oriented to shoppers' real needs as opposed to gadgetization.

Second, the behavioral approach has been consistently used to research customers' behavior within an omnichannel context. For example, several researchers adopt a behavioral approach to analyze customer segments that use complaint channels differently [40]. Furthermore, Shen et al. [9] show that channel integration quality impacts perceived fluency across channels. Moreover, the perceived fluency explains 55\% of the variance in omnichannel service usage while internal usage and external usage experience moderate this relationship. Additionally, Taylor and Levin [37] explored consumer interest in the retailer's mobile app as an attitudinal predictor of two behavioral outcomes, shopping and information-sharing and found that a user's interest in a retail app is related to his intention to engage in both purchasing and information-sharing activities.

\subsubsection{Theories on Technology Adoption}

Research on technology adoption is grounded mainly in two theoretical frameworks, Theory of Planned Behavior (TPB) and Technology Acceptance Model (TAM) [66].

As an extension of the Theory of Reasoned Action (TRA), TPB was introduced by Ajzen in 1985 [67] and points out that attitude towards behavior, subject norms, and perceived behavioural control, together shape a person's behavioural intention that subsequently influences his actual behavior. Based on this view, $\mathrm{Xu}$ and Jackson [68] researched customer channel selection intention in an omnichannel context and found that channel transparency, channel convenience and channel uniformity have a positive impact on customers' perceived behavioral control. Additionally, authors found customer perceived behavioral control and channel price advantage have a positive impact on channel selection intention, while perceived risk has a negative effect.

TAM is an information systems theory proposed by Davis [69] in 1985 that has been massively used to explain the adoption process of new technologies. In the context of our research, having identified several studies based on TAM is coherent with at least two major research streams: customer behavior research in omnichannel context and customer interaction with technology literature. In this context, we found TAM was used to explain intention to adopt digital services [70] and how brand experience strongly affects the behavioral intention to use [71].

\subsubsection{Expectancy Theory}

Another commonly used theoretical lens to understand an individual's behavior with technology is Expectancy Theory that stands that users will behave in a certain way when looking to maximize positive outcomes and minimize others [72]. Based on expectancy theory, Wetzlinger et al. [70] researched the impact of personalization on privacy concerns and customer's intention to adopt services in physical and online stores and found that personalized services cause much more privacy concerns than non-personalized services in both contexts.

\subsubsection{Anticipated Utility Theory}

Based on Anticipated Utility Theory [73], Herhausen et al. [46] segment customers by their use of specific touchpoints in their customer journey and investigate loyalty formation across segments. From the perspective of anticipated utility theory, customer journey is a decision making process and the usage of a touchpoint during the journey depends on the anticipated utility for each individual customer. 


\subsubsection{Diffusion-of-Innovations Theory (DIT)}

A topic that draws the attention of several researchers is channel choice and the omnichannel shopping intention as one of current topics in omnichannel research. Several researchers [58,59,74], frame their work on the Diffusion-of-Innovations Theory, one dominant approach used to research omnichannel CX-related topics. DIT was first introduced by Everett Rogers in 1962 [75] and states that adoption decisions of new technologies are influenced by characteristics of the technology itself and the characteristics of the user. From this perspective, one of the challenges in omnichannel management is understanding the stimuli and technology triggers that have an influence on omnichannel adoption.

The findings of Costa e Silva et al. [71] suggest that perceptions of usefulness, ease of use and compatibility have a positive impact on brand experience which strongly affects the behavioral intention to use. Moreover, Kim et al. [74] show that the perceptions of relative advantage, complexity, compatibility and risk involved in online shopping are related to the intention to use buy-online, pick-up in-store and this relationship is moderated by locational convenience and product involvement. Drawing on technology adoption research and diffusion of innovations theory, [59] show that perceptions of service quality and risk of the Internet store mediate the effect of online-offline channel integration, while customer's online shopping experience moderates it. More recently, Shi et al. [56] found that compatibility and risk perception are significant determinants of the customer's omnichannel shopping intention.

\subsubsection{Unified Theory of Acceptance and Use of Technology (UTAUT, UTAUT2)}

These three theories (TAM, DIT and TPB) were among the fundamentals of UTAUT, a model that includes four determining factors for intention to use: performance expectancy, effort expectancy, social influence and facilitating conditions [76]. In the omnichannel CX literature, UTAUT was used by Demko-Rihter and ter Halle [49] to introduce an application that enhances the in-store shopping experience while integrating e-commerce and $\mathrm{m}$-commerce.

In 2012, the UTAUT model evolved to UTAUT2 with the addition of hedonic motivation, price value and habit as determinants for behavioral intention. In our SLR, we found Juaneda-Ayensa et al. [8] to use UTAUT2 and two additional factors-personal innovativeness and perceived security - to explore the factors that influence omnichannel customer's behavior. The authors found that the key drivers of purchase intention in an omnichannel context are personal innovativeness, effort expectancy, and performance expectancy.

\subsubsection{Other Theoretical Perspectives}

Finally, a number of other theories have been adopted to study the omnichannel phenomenon, such as self determination theory [38], attribution theory [10,51], uses and gratifications theory and means-end chain theory (based on expectancy-value theory) [47], justice theory [51], dual coding theory [77], dynamic capabilities theory [22], resource advantage theory of competition [30], complexity theory [41] and complex adaptive theory [53]. In two studies, authors adopt an interpretive perspective in order to gain a deep understanding of the challenges related to providing a seamless shopping experience, particularly in terms of last mile fulfilment and distribution [7] and online retail management [54].

It is worth noting that adopting different theoretical lenses does not mean that the respective results live in isolation, quite the opposite. First, several theories arose on the basis of others so they are related. TAM, for example, emerged from the TPB that was adapted by modeling how people use and adopt a technology. Second, these theoretical lenses came from inter-related broader disciplines such as marketing, sociology and computer science, illustrating the importance of a broad view of the decision-making process and human behavior. For future research purposes, the academic implication of this theoretical mapping is that in order to dive deep into a research subject, research teams should adopt a wide perspective backed by a general awareness of these interconnected disciplines. Third, 
our research strategy is integrative itself as it is built on node-type elements that link the results of previous research allowing us to give a sense of unity in this body of knowledge.

\section{Discussion}

We aimed to discover how academia is addressing CX in an omnichannel context and what the underlying research streams are, using a SLR methodology. Analyzing the results of the research corpus allowed us to highlight there is a wide variety of topics being investigated based on different theoretical perspectives. From the consumer point of view, the literature reveals an extensive research stream dedicated to customer behavior, customer segmentation, and customer interaction with in-store technology. From the organizational perspective, the most common topics covered so far are omnichannel management and service quality. In this context, we stress it is important for researchers and practitioners to situate their work in the omnichannel CX or omnichannel CX management spectrum. Authors have adopted this perspective when describing an omnichannel organization [2] or defining CX [15].

Although omnichannel has been investigated for more than ten years, omnichannel $\mathrm{CX}$ as a specific topic is still seldom explored. A large part of the existing studies focus on the shopping experience and some studies on claims, while we see opportunities to address in terms of the customer lifecycle big picture; meaning the omnichannel CX in time.

Some scopes overlap and it is particularly in these shared spaces of knowledge that lies the opportunity to integrate the research field and future work possibilities emerge. By approaching omnichannel CX management from an integrated theoretical perspective, future work would need to propose guidelines for practical assessment, measurement and evaluation. We intend to address this challenge in our future work.

Although our results are coherent with the string used to select the papers, we were expecting to encounter more interdisciplinary work. Therefore, we identify future research opportunities in the interdisciplinary work for addressing omnichannel experience, e.g., in the interplay between marketing, management, and computer science.

From an academic perspective, the fact that most of the empirical studies came from five countries (Spain, China, UK, Germany, USA) shows that there may be a gap in terms of academic research coming from other cultural realities-or at least in terms of academic publications.

As an insight for researchers, vocabulary is fundamental when asking questions. Although both "channel" and "omnichannel" concepts are highly familiar for retail practitioners and researchers, this is not the case for consumers. Therefore, qualitative work involving customers must consider adapting their language to the customers' mental references and eventually considering capturing data using different methodologies rather than surveys or interviews. When asked directly about omnichannel concepts, participants were poorly or not at all familiar with "omnichannel" concepts [56,78]. Moreover, consumers perceive that they live an experience with a brand rather than with a channel [78].

Naturally, our results should be understood with their own limitations. First, our SLR was built upon published research results that we included based on a specific string. Other papers might have addressed omnichannel CX and its management by using different terminology or without specifically analyzing CX elements in the omnichannel context. Second, the research was performed in specific academic databases, which also means that potential interesting publications coming from other sources might have been excluded. Although we acknowledge that no single source will find all of the primary studies [79], when running a SLR, it is essential to include a good sample of papers to respond to the research questions rather than considering all the papers ever written. Based on this argument, after the first initial screen, we considered it was not necessary to expand the search to other databases than the ones we included in the first place. Third, even if we aimed to minimize researcher bias by having two researchers iterate on the included papers, this type of bias is practically inevitable and cannot be fully removed from an SLR study. Fourth, as we show in the descriptive analysis, the selected papers come from 
different industries, countries and retail-specific contexts. Given this variety of contexts, it is obviously complex to compare and generalize the results or to extend them as they are to different contexts. However, by adopting an integrative strategy we aimed to give a sense to different research streams arising from different theoretical perspectives.

\section{Future Research Agenda}

In this section we propose a research agenda for addressing the research gaps identified during our SLR. These gaps include research questions and topics that emerge from analyzing the existing contributions in the omnichannel CX field. In the following, we discuss a future research agenda from both an academic and practitioner perspective. There is no specific criteria behind the order in which the topics are presented rather than providing a sound narrative. The proposed research agenda is summarized in Table 3.

Table 3. Future research agenda.

\begin{tabular}{|c|c|c|}
\hline Omnichannel CX Stream & $\begin{array}{l}\text { Potential Future Research Questions in the } \\
\text { Omnichannel CX Landscape }\end{array}$ & Practical Application \\
\hline $\begin{array}{l}\text { Operationalization of } \\
\text { omnichannel CX }\end{array}$ & What are the elements of the omnichannel CX? & $\begin{array}{ll}\text { - } & \text { Guidelines } \\
\text { - } & \text { self-assessment tools }\end{array}$ \\
\hline $\begin{array}{l}\text { Customer lifecycle in an } \\
\text { omnichannel context }\end{array}$ & $\begin{array}{l}\text { - How can we map the customer experience } \\
\text { during the customer lifetime? } \\
\text { - How to build a compelling brand experience } \\
\text { through multiple touchpoints? } \\
\text { How to translate brand experience goals into } \\
\text { channel goals? }\end{array}$ & $\begin{array}{l}-\quad \text { Extend the use of customer journey } \\
\text { - } \quad \text { Brand experience design }\end{array}$ \\
\hline $\begin{array}{l}\text { Managing omnichannel CX } \\
\text { on marketplaces }\end{array}$ & $\begin{array}{l}\text { What are the long-term effects of selling on a } \\
\text { marketplace on customer CX? }\end{array}$ & $\begin{array}{l}\text { Guidelines for brand, price, content and } \\
\text { service consistency }\end{array}$ \\
\hline $\begin{array}{l}\text { New touchpoints } \\
\text { integration }\end{array}$ & $\begin{array}{l}\text { - How to properly integrate social media into the } \\
\text { customer journey beyond the purchase stage? } \\
\text { - } \quad \text { Consumer-brand versus peer-to-peer touchpoints } \\
\text { How can brands better leverage community } \\
\text { digital channels in an omnichannel context? }\end{array}$ & $\begin{array}{l}\text { - Social media management and } \\
\text { outsourcing guidelines }\end{array}$ \\
\hline $\begin{array}{l}\text { Predictors for omnichannel } \\
\text { customer behavior }\end{array}$ & $\begin{array}{l}\text { - How can we collect behavioral data allowing us } \\
\text { to predict future behavior? } \\
\text { - How can we opportunely empower front-end } \\
\text { executives with this data? }\end{array}$ & $\begin{array}{l}\text { - Anticipate user's behavior. } \\
\text { Empower front-end customer care } \\
\text { teams. }\end{array}$ \\
\hline Omnichannel services & $\begin{array}{l}\text { - What are the key elements of omnichannel CX } \\
\text { for service-based companies? }\end{array}$ & $\begin{array}{l}\text { - Best practices and guidelines for } \\
\text { industry }\end{array}$ \\
\hline
\end{tabular}

\subsection{Operationalization of Omnichannel CX}

Omnichannel CX emerges as a co-constructed space between the organization and the consumer. We argue that despite the fact that omnichannel as an approach has been highly explored in the past years, the omnichannel $\mathrm{CX}$ as a construct has not been operationalized enough. Few studies have explored the dimensions of omnichannel CX. Mapping the dimensions and elements of omnichannel CX would provide managers with practical guidelines to apply at different management levels, as well as to self-assess and evaluate the maturity level of their organization in terms of omnichannel CX. Our intention is to address the operationalization of omnichannel $C X$ as a multidimensional construct in the near future. Although recent research stresses the fact that omnichannel per se might be an utopia [80] and the omnichannel concept is a company-related construct-not a customer one-we believe that adopting an omnichannel approach makes sense for most companies, especially for those ones that were not born digital. Consequently, as internal teams tend to create new channels and touchpoints in order to respond to changing customer behavior, guidelines and best practices should orient their practice.

In this context, although there might not be a unique perspective, based on our findings, we see a difference between omnichannel CX and omnichannel CX management. 
The first one-omnichannel CX-is co-constructed between the customer and the company, while the second one-omnichannel CX management-is a multidimensional construct. At some point in the future, once the maturity level of the companies in terms of $C X$ will grow, the omnichannel variable will probably be included in the CX concept, meaning a true meaningful $C X$ will be omnichannel. Therefore speaking about omnichannel $C X$ will be redundant.

\subsection{Customer Lifecycle in an Omnichannel Context}

As several scholars $[9,34,38,46,47,59,61,71,81]$, we also call for longitudinal research on omnichannel CX. Most of the studies have been dedicated to the purchase intent while we see there is still a lack of foundations of the $C X$ research on a medium and long term basis during the customer lifetime cycle, going beyond the purchase journey. In our view, the pre-purchase journey itself could be explored by addressing the pre-purchase behavior based on segmentation predictors, information search and previous experiences.

The post-purchase journey has been researched mainly in the context of customer complaints [39-42]. Nevertheless, we believe other research avenues related to the postpurchase journey could include customer segments evolution in time (or dynamic segmentation), cross-channel orchestration, CX measurement in an omnichannel context. Moreover, gaining a better understanding on how to build a compelling brand experience in time through multiple touchpoints and how to translate brand experience goals into channel goals would inform both researchers and practitioners.

\subsection{Managing Omnichannel CX on Marketplaces}

Building on this long term perspective of the customer lifecycle, a question that should resonate for both academia and practitioners is "What are the long-term effects of selling on a marketplace on customer CX?" None of the included papers explores the impact on omnichannel CX when retailers extend their channels to a marketplace. Data from the industry states that depending on the product category, the shopping journey can start in marketplaces such as Amazon rather than on search engines such as Google or directly on the brand's website. Only in the US market, up to $63 \%$ of the customers start their purchase journey on Amazon, while in Germany and Spain, $82 \%$ and $83 \%$ of searches start with Amazon respectively [82]. The challenge of selling and building a brand through a marketplace is increasing, yet the discussion is still open, for both practitioners and scholars, of whether this is a good decision. However, recent research finds that brand building on a marketplace works [83] but the impact on sales is category-specific and it depends on retailer's assortment characteristics per category. We see this as an opportunity for future research to address the specific context of marketplaces in an omnichannel CX approach.

Local and international marketplaces (such as Amazon or eBay) represent an important market share in several product categories purchase journeys, we see this as an important research opportunity. As other researchers agree [80] adding new sales channels through marketplaces is a specific context that makes it difficult to transfer existing knowledge from cross-channel relationships to the marketplaces context. Difficulties emerge at different levels. First, a marketplace store is a shared space where the brand owner can not control websites attributes, the checkout process or even the customer relationship management, elements that impact the $C X$ with the sales process. Second, usually marketplaces do not share customer data with the sellers, so it might be difficult for the store owner to even solve a short term need as to contact customers for CX research and even more difficult to engage into a omnichannel $C X$ approach. Third, additional cross-channel challenges arise with elements like brand, price, content and service consistency. Therefore, we suggest that research in the future should consider the case of marketplaces as a research stream in an omnichannel context. 


\subsection{New Touchpoints Integration}

In an omnichannel context, it is fundamental to broaden the channel scope by integrating multiple customer touchpoints [2]. In this perspective, a specific channel as the physical store can include more than one touchpoint: the physical space itself, a technology, and the sales or customer service executives. Moreover, the more the mobile technology is shaping the retailers' relationship with the customers, the more the industry moves to a phygital experience- that incorporates new touchpoints such as touchscreens, connected mirrors, NFC [51,52], QR codes [51] or interaction models as virtual expert and digital assistant [50]. Overall, incorporating new technologies in the physical store was found to positively impact the purchase intention [81]. As a result, new interaction types emerge such as adding voice to mobile applications, which creates a more natural but also more complex environment to interact with consumers. In this direction, Pagani et al. [77] findings show that adding voice to a platform has a counterintuitive effect and reduces the user's engagement with the brand. Merging digital and physical interactions in the customer journey and during the customer lifecycle is a continuous challenge in an omnichannel approach. As Dhebar [84] states, there is a need for an holistic perspective when it comes to customer experience including the totality of touchpoints and all stages of the customer relationship cycle.

In a SLR on omnichannel management, Lehrer and Jung [27] found that social media integration was rarely covered by the past research on omnichannel approach. With our SLR, four years after, we found this gap is still unleveraged. While companies often outsource the management of social media, research might suggest that it is preferable to integrate social media as relevant touchpoints throughout the customer lifecycle.

Moreover, given the fact that even another customer could be a touchpoint and the rise of user-generated content is adding complexity to the customer-brand relationship, new CX challenges arise. Therefore, consumer-brand versus peer-to-peer touchpoints [85] should be addressed by further investigation. As we mentioned, only $6 \%$ of the 133 mapped touchpoints involved peer-to-peer interactions. Indeed, word of mouth (WOM) and electronic word of mouth (eWOM) are considered one of the most influential sources for decision-making [86-88]. Hence, future research could address the role of the WOM and eWOM in an omnichannel context.

Moreover, we found no community digital channels being studied among the selected papers. Community channels like forums, blogs, YouTube or Vimeo allow a two-way communication between customers [89].

Finally, as stated in the descriptive review, little attention has been dedicated to call center integration. This might be explained by the fact that for marketing and management scholars there is not much interest in researching call center integration, disregarding its eventual importance for the industry.

\subsection{Predictors for Omnichannel Customer Behavior}

Over the years, research has aimed to understand how companies can foster customers to adopt omnichannel behavior. For example, we might want to explore how to collect behavioral data allowing us to predict future omnichannel behavior or how to opportunely empower front-end executives with this data in order to help them better shape the CX. From this perspective, future research should consider using objective data based on historical transactions with a company-as transactions data from customer credit cards [59] — and anonymized behavioral usage data from third party data sources such as Google Analytics or social media behavior.

\subsection{Omnichannel Services}

As highlighted in the results of this review, only $28 \%$ of the included studies have approached CX in an omnichannel context with services. Omnichannel is still very related to retailing. Nevertheless, in a context of servitization of the economy, we argue that service-based business should embrace an omnichannel strategy as well. In this context, 
a major question to respond to is "What are the key elements of omnichannel CX for service-based companies?"

\section{Conclusions}

Omnichannel as a managerial approach for CX is here to stay. Organizations beyond retailing will embrace this strategy in order to maintain their competitiveness, deliver a seamless experience across-channels and ensure a sustainable future. Adopting a customercentric business approach will require the entire organization to be articulated from inside out. Through the SLR, we identified the main research streams around the omnichannel CX, highlighted significant contributions and connected the dots between a fragmented body of knowledge. Moreover, by mapping the theoretical lenses different authors adopted to address specific topics, we aimed to make sense of these perspectives and foster an unified understanding of omnichannel CX. We also identified research gaps in this body of knowledge that we translated into a research agenda.

In the context of our findings, we understand the omnichannel CX as a co-created construct that arises during each interaction between a brand and a customer along the entire customer lifecycle, including all available touchpoints and channels where this interaction occurs.

In terms of managerial implications, these findings allow us to anticipate two main needs. First, the need to articulate omnichannel CX management based on interdisciplinary teams integrating marketing, management, technology, design, and social sciences capabilities. For instance, understanding customers to identify meaningful customer segments requires data analytics capabilities at the same level as it requires a behavioral and psychology background. As explained in the findings (Section 4), customer segmentation has become more sophisticated and goes far beyond the usage of sociodemographic data. Understanding customer behavior during the entire customer lifecycle will enrich this segmentation. Dynamic segmentation-meaning a process that evolves in time-will also allow managers to continuously adapt their strategies to changing customer behaviors.

Second, an omnichannel strategy requires the entire organization to adopt a customercentric culture, requiring a strong organizational articulation where the human factor-not only customers (meaning all teams and ecosystem) —will be a fundamental axis.

Third, managers in service industries should also embrace omnichannel practices. As our findings show, omnichannel as an approach to CX is not a characteristic of retailing any more. The more companies from other industries will adopt it as a strategy, the more they will set new expectations on the market. Moreover, B2B managers should also consider adopting an omnichannel strategy. In an era where boundaries between social and professional life are more and more blurred, people expect to connect with brands in a similar way.

Fourth, creating new touchpoints does not always mean customers engage more with a brand. Therefore, managers should adopt an experimentation path informed by data. Tracking customer behavior and the responses to their business strategies will allow them to decide on an ongoing basis and adjust their tactics accordingly.

Finally, our future work intends to enhance this field by operationalizing the coconstructed concept of omnichannel CX. As organizations continue to add new channels and touchpoints allowing their customers to interact with the brand, articulating these interaction spaces will require guidelines and best practices to adapt to each context.

Author Contributions: Conceptualization and methodology: C.G. and V.H.; SLR investigation; C.G., F.G.-L.; writing—original draft preparation, C.G.; writing—-review and editing, C.G., F.G.-L., V.H.; supervision, V.H. All authors have read and agreed to the published version of the manuscript.

Funding: This research was supported by the Fondecyt (Conicyt/ANID) Grant 1181162, and by the VRI Postdoctoral research Grant (Pontificia Universidad Católica de Chile).

Informed Consent Statement: Not applicable. 
Data Availability Statement: Data sharing not applicable. No new data was created or analyzed in this study. Data sharing is not applicable to this article.

Conflicts of Interest: The authors declare no conflict of interest. The funders had no role in the design of the study; in the collection, analyses, or interpretation of data; in the writing of the manuscript, or in the decision to publish the results.

\section{Appendix A}

Table A1. Selected papers.

\begin{tabular}{|c|c|c|c|c|}
\hline Year & Authors & Title & Source & Reference \\
\hline 2014 & $\begin{array}{l}\text { Ervasti, M., Isomursu, M., } \\
\text { Mäkelä, S.-M. }\end{array}$ & $\begin{array}{l}\text { Enriching Everyday Experience with a } \\
\text { Digital Service: Case Study in Rural } \\
\text { Retail Store }\end{array}$ & Bled eConference 2014 & [48] \\
\hline 2014 & Taylor, D.G., Levin, M. & $\begin{array}{l}\text { Predicting mobile app usage for } \\
\text { purchasing and information-sharing }\end{array}$ & $\begin{array}{l}\text { International Journal of Retail } \\
\text { \& Distribution Management }\end{array}$ & [37] \\
\hline 2015 & Demko-Rihter, J., ter Halle, I. & $\begin{array}{l}\text { Revival of high street retailing-the } \\
\text { added value of shopping apps }\end{array}$ & Amfiteatru Economic & [49] \\
\hline 2015 & $\begin{array}{l}\text { Peltola, S., Vainio, H., } \\
\text { Nieminen, M. }\end{array}$ & $\begin{array}{l}\text { Key factors in developing } \\
\text { omnichannel customer experience } \\
\text { with finnish retailers }\end{array}$ & $\begin{array}{l}\text { International Conference on } \\
\mathrm{HCI} \text { in Business }\end{array}$ & [43] \\
\hline 2015 & $\begin{array}{l}\text { Herhausen D., Binder J., } \\
\text { Schoegel M., Herrmann A. }\end{array}$ & $\begin{array}{l}\text { Integrating Bricks with Clicks: } \\
\text { Retailer-Level and Channel-Level } \\
\text { Outcomes of Online-Offline Channel } \\
\text { Integration }\end{array}$ & Journal of Retailing & [59] \\
\hline 2016 & Parise, S., Guinan, P.J., Kafka, R. & $\begin{array}{l}\text { Solving the crisis of immediacy: How } \\
\text { digital technology can transform the } \\
\text { customer experience }\end{array}$ & Business Horizons & {$[50]$} \\
\hline 2016 & $\begin{array}{l}\text { Juaneda-Ayensa, E., } \\
\text { Mosquera, A., Sierra Murillo, Y. }\end{array}$ & $\begin{array}{l}\text { Omnichannel Customer Behavior: } \\
\text { Key Drivers of Technology } \\
\text { Acceptance and Use and Their Effects } \\
\text { on Purchase Intention }\end{array}$ & Frontiers in Psychology & [8] \\
\hline 2016 & $\begin{array}{l}\text { Bernon, M., Cullen J., } \\
\text { Gorst, J. }\end{array}$ & $\begin{array}{l}\text { Online retail returns management: } \\
\text { Integration within an omni-channel } \\
\text { distribution context }\end{array}$ & $\begin{array}{l}\text { International Journal of } \\
\text { Physical Distribution \& } \\
\text { Logistics Management }\end{array}$ & {$[54]$} \\
\hline 2016 & $\begin{array}{l}\text { Hübner, A., Kuhn, H., } \\
\text { Wollenburg, J. }\end{array}$ & $\begin{array}{l}\text { Last mile fulfilment and distribution } \\
\text { in omni-channel grocery retailing: A } \\
\text { strategic planning framework }\end{array}$ & $\begin{array}{l}\text { International Journal of Retail } \\
\text { \& Distribution Management }\end{array}$ & [7] \\
\hline 2017 & $\begin{array}{l}\text { Zagel, C., Niels, A., } \\
\text { Bodendorf, F. }\end{array}$ & $\begin{array}{l}\text { Using Smartphones for Information } \\
\text { Retrieval in Omnichannel } \\
\text { Scenarios-Assessing the } \\
\text { Effectiveness of Technological Triggers }\end{array}$ & $\begin{array}{l}\text { AHFE } 2016 \text { International } \\
\text { Conference on The Human } \\
\text { Side of Service Engineering }\end{array}$ & [51] \\
\hline 2017 & $\begin{array}{l}\text { Pascoe, M., Wright, O., } \\
\text { Winzar, H. }\end{array}$ & $\begin{array}{l}\text { Using best-worst scaling to reveal } \\
\text { perceived relative importance of } \\
\text { website attributes }\end{array}$ & $\begin{array}{l}\text { Asia Pacific Journal of } \\
\text { Marketing } \\
\text { and Logistics }\end{array}$ & [90] \\
\hline 2017 & $\begin{array}{l}\text { Rajan, C.R., Swaminathan, T.N., } \\
\text { Pavithra, M.R. }\end{array}$ & $\begin{array}{l}\text { Key Drivers of Purchase Intent by } \\
\text { Indian Consumers in Omni-Channel } \\
\text { Shopping }\end{array}$ & Indian Journal of Marketing & [91] \\
\hline 2017 & $\begin{array}{l}\text { Frasquet, M., Miquel, M.J., } \\
\text { Mollá, A. }\end{array}$ & $\begin{array}{l}\text { Complaining at the Store or Through } \\
\text { Social Media: The Influence of the } \\
\text { Purchase Channel, Satisfaction, and } \\
\text { Commitment }\end{array}$ & $\begin{array}{l}\text { International Conference in } \\
\text { Advances in National Brand } \\
\text { and Private Label Marketing }\end{array}$ & [39] \\
\hline
\end{tabular}


Table A1. Cont.

\begin{tabular}{|c|c|c|c|c|}
\hline Year & Authors & Title & Source & Reference \\
\hline 2017 & $\begin{array}{l}\text { Carnein, M., Heuchert, M., } \\
\text { Homann, L., Trautmann, H., } \\
\text { Vossen, G., Becker, J., Kraume, K. }\end{array}$ & $\begin{array}{l}\text { Towards Efficient and Informative } \\
\text { Omni-Channel Customer Relationship } \\
\text { Management }\end{array}$ & $\begin{array}{l}\text { International Conference on } \\
\text { Conceptual Modeling }\end{array}$ & {$[35]$} \\
\hline 2017 & $\begin{array}{l}\text { Wetzlinger, W., Auinger, A., } \\
\text { Kindermann, H., } \\
\text { Schönberger, W. }\end{array}$ & $\begin{array}{l}\text { Acceptance of Personalization in } \\
\text { Omnichannel Retailing }\end{array}$ & $\begin{array}{l}\text { International Conference on } \\
\mathrm{HCI} \text { in Business, Government, } \\
\text { and Organizations }\end{array}$ & {$[70]$} \\
\hline 2017 & $\begin{array}{l}\text { Murfield, M., Christopher, A.B., } \\
\text { Rutner, P., Thomas, R. }\end{array}$ & $\begin{array}{l}\text { Investigating logistics service quality } \\
\text { in omni-channel retailing }\end{array}$ & $\begin{array}{l}\text { International Journal of } \\
\text { Physical Distribution \& } \\
\text { Logistics Management }\end{array}$ & {$[55]$} \\
\hline 2017 & $\begin{array}{l}\text { Saghiri, S., Wilding, R., Mena, C., } \\
\text { Bourlakis, M. }\end{array}$ & $\begin{array}{l}\text { Toward a three-dimensional } \\
\text { framework for omni-channel }\end{array}$ & Journal of Business Research & [53] \\
\hline 2017 & $\begin{array}{l}\text { Huré, E., Picot-Coupey, K., } \\
\text { Ackermann, C.-L. }\end{array}$ & $\begin{array}{l}\text { Understanding omni-channel } \\
\text { shopping value: A mixed-method } \\
\text { study }\end{array}$ & $\begin{array}{l}\text { Journal of Retailing and } \\
\text { Consumer Services }\end{array}$ & {$[62]$} \\
\hline 2017 & $\begin{array}{l}\text { Kumar, V., Rajan, B., Gupta, S., } \\
\text { Dalla, Pozza I. }\end{array}$ & Customer engagement in service & $\begin{array}{l}\text { Journal of the Academy of } \\
\text { Marketing Science }\end{array}$ & {$[60]$} \\
\hline 2017 & Mahrous, A., Hassan, S.S. & $\begin{array}{l}\text { Achieving Superior Customer } \\
\text { Experience: An Investigation of } \\
\text { Multichannel Choices in the Travel } \\
\text { and Tourism Industry of an Emerging } \\
\text { Market }\end{array}$ & Journal of Travel Research & [34] \\
\hline 2017 & Kaczorowska-Spychalska D. & $\begin{array}{l}\text { Consumer perspective of omnichannel } \\
\text { commerce }\end{array}$ & $\begin{array}{l}\text { Management: The Journal of } \\
\text { University of Zielona Góra }\end{array}$ & [57] \\
\hline 2017 & Lee, S., Lim, T.-S. & $\begin{array}{l}\text { Retailer's Innovative Differentiation } \\
\text { Method Based on Customer } \\
\text { Experience: Focusing Mediating Effect } \\
\text { of Omni-channel Shopper Type }\end{array}$ & Quality Innovation Prosperity & [45] \\
\hline 2017 & Kim, E., Park, M.-C., Lee, J. & $\begin{array}{l}\text { Determinants of the intention to use } \\
\text { Buy-Online, Pickup In-Store (BOPS): } \\
\text { The moderating effects of situational } \\
\text { factors and product type }\end{array}$ & Telematics and Informatics & {$[74]$} \\
\hline 2018 & $\begin{array}{l}\text { Li, Y., Liua, H., Limb, E.T.K., } \\
\text { Goh, J.M., Yanga, F., Lee M.K.O }\end{array}$ & $\begin{array}{l}\text { Customer's reaction to cross-channel } \\
\text { integration in omnichannel retailing: } \\
\text { The mediating roles of retailer } \\
\text { uncertainty, identity attractiveness, } \\
\text { and switching costs }\end{array}$ & Decision Support Systems & [81] \\
\hline 2018 & $\begin{array}{l}\text { Shen, X.-L., Li Y.-J., Sun, Y., } \\
\text { Wang, N. }\end{array}$ & $\begin{array}{l}\text { Channel integration quality, perceived } \\
\text { fluency and omnichannel service } \\
\text { usage: The moderating roles of } \\
\text { internal and external usage experience }\end{array}$ & Decision Support Systems & [9] \\
\hline 2018 & $\begin{array}{l}\text { Belghiti, S., Ochs, A., Lemoine, } \\
\text { J.-F., Badot, O. }\end{array}$ & $\begin{array}{l}\text { The Phygital Shopping Experience: } \\
\text { An Attempt at Conceptualization and } \\
\text { Empirical Investigation }\end{array}$ & $\begin{array}{l}\text { Developments in Marketing } \\
\text { Science: Proceedings of the } \\
\text { Academy of Marketing Science }\end{array}$ & [52] \\
\hline 2018 & $\begin{array}{l}\text { Xiao, L., Guo, Z., } \\
\text { D'Ambra, J. }\end{array}$ & $\begin{array}{l}\text { Benefit-based } \mathrm{O} 2 \mathrm{O} \text { commerce } \\
\text { segmentation: a means-end chain } \\
\text { approach }\end{array}$ & Electronic Commerce Research & [47] \\
\hline 2018 & $\begin{array}{l}\text { Zhang, M., Ren, C., Wang, G.A., } \\
\text { He, Z. }\end{array}$ & $\begin{array}{l}\text { The impact of channel integration on } \\
\text { consumer responses in omnichannel } \\
\text { retailing: The mediating effect of } \\
\text { consumer empowerment }\end{array}$ & $\begin{array}{l}\text { Electronic Commerce Research } \\
\text { and Applications }\end{array}$ & {$[61]$} \\
\hline
\end{tabular}


Table A1. Cont.

\begin{tabular}{|c|c|c|c|c|}
\hline Year & Authors & Title & Source & Reference \\
\hline 2018 & $\begin{array}{l}\text { Wang, Y.J., Capon, N., } \\
\text { Wang, V.L., Guo, C. }\end{array}$ & $\begin{array}{l}\text { Building industrial brand equity on } \\
\text { resource advantage }\end{array}$ & $\begin{array}{l}\text { Industrial Marketing } \\
\text { Management }\end{array}$ & {$[30]$} \\
\hline 2018 & $\begin{array}{l}\text { Komulainen, } \mathrm{H} ., \\
\text { Makkonen, } \mathrm{H} \text {. }\end{array}$ & $\begin{array}{l}\text { Customer experience in omni-channel } \\
\text { banking services }\end{array}$ & $\begin{array}{l}\text { Journal of Financial Services } \\
\text { Marketing }\end{array}$ & {$[31]$} \\
\hline 2018 & Barwitz, N., Maas, P. & $\begin{array}{l}\text { Understanding the Omnichannel } \\
\text { Customer Journey: Determinants of } \\
\text { Interaction Choice }\end{array}$ & $\begin{array}{l}\text { Journal of Interactive } \\
\text { Marketing }\end{array}$ & {$[32]$} \\
\hline 2018 & $\begin{array}{l}\text { Rosenmayer, A., } \\
\text { McQuilken, L., } \\
\text { Robertson, N., Ogden S. }\end{array}$ & $\begin{array}{l}\text { Omni-channel service failures and } \\
\text { recoveries: refined typologies using } \\
\text { Facebook complaints }\end{array}$ & Journal of Services Marketing & {$[42]$} \\
\hline 2018 & $\begin{array}{l}\text { Mosquera, A., Olarte-Pascual, C., } \\
\text { Juaneda-Ayensa, E., } \\
\text { Sierra Murillo, Y. }\end{array}$ & $\begin{array}{l}\text { The role of technology in an } \\
\text { omnichannel physical store. Assessing } \\
\text { the moderating effect of gender }\end{array}$ & Spanish Journal of Marketing & [92] \\
\hline 2019 & $\begin{array}{l}\text { Ribamar Siqueira Jr, J., García } \\
\text { Peña, N., ter Horst E., Molina, G. }\end{array}$ & $\begin{array}{l}\text { Spreading the Word: How Customer } \\
\text { Experience in a Traditional Retail } \\
\text { Setting Influences Consumer } \\
\text { Traditional and Electronic } \\
\text { Word-of-mouth Intention }\end{array}$ & $\begin{array}{l}\text { Electronic Commerce Research } \\
\text { and Applications }\end{array}$ & [93] \\
\hline 2019 & $\begin{array}{l}\text { Lee, Z.W.Y, Chan, T.K.H., Chong } \\
\text { A.Y.-L., Thadani, D.R. }\end{array}$ & $\begin{array}{l}\text { Customer engagement through } \\
\text { omnichannel retailing: The effects of } \\
\text { channel integration quality }\end{array}$ & $\begin{array}{l}\text { Industrial Marketing } \\
\text { Management }\end{array}$ & [94] \\
\hline 2019 & $\begin{array}{l}\text { Hossain, T.M.T., Akter, S., } \\
\text { Kattiyapornpong, U., } \\
\text { Dwivedi, Y. }\end{array}$ & $\begin{array}{l}\text { Reconceptualizing Integration Quality } \\
\text { Dynamics for Omnichannel Marketing }\end{array}$ & $\begin{array}{l}\text { Industrial Marketing } \\
\text { Management }\end{array}$ & {$[22]$} \\
\hline 2019 & $\begin{array}{l}\text { Rebaque-Rivas, P., } \\
\text { Gil-Rodríguez, E. }\end{array}$ & $\begin{array}{l}\text { Adopting an Omnichannel Approach } \\
\text { to Improve User Experience in Online } \\
\text { Enrolment at an E-learning University }\end{array}$ & $\begin{array}{l}\text { International Conference on } \\
\text { Human-Computer Interaction }\end{array}$ & [36] \\
\hline 2019 & Xu, X., Jackson, J.E. & $\begin{array}{l}\text { Examining customer channel selection } \\
\text { intention in the omni-channel retail } \\
\text { environment }\end{array}$ & $\begin{array}{l}\text { International Journal of } \\
\text { Production Economics }\end{array}$ & [68] \\
\hline 2019 & $\begin{array}{l}\text { Kim, R.B., Matsui, T., } \\
\text { Park, J., Okutani, T. }\end{array}$ & $\begin{array}{l}\text { Perceived Consumer Value of } \\
\text { Omni-Channel Service Attributesin } \\
\text { Japan and Korea }\end{array}$ & $\begin{array}{l}\text { Inzinerine } \\
\text { Ekonomika-Engineering } \\
\text { Economics }\end{array}$ & [78] \\
\hline 2019 & $\begin{array}{l}\text { Pagani, M., Racat, M., } \\
\text { Hofacker, C.F. }\end{array}$ & $\begin{array}{l}\text { Adding Voice to the Omnichannel and } \\
\text { How that Affects Brand Trust }\end{array}$ & $\begin{array}{l}\text { Journal of Interactive } \\
\text { Marketing }\end{array}$ & [77] \\
\hline 2019 & $\begin{array}{l}\text { Costa e Silva, S., Carvalho } \\
\text { Martins, C., de Sousa, J.M. }\end{array}$ & $\begin{array}{l}\text { Omnichannel approach: Factors } \\
\text { affecting consumer acceptance }\end{array}$ & Journal of Marketing Channels & {$[71]$} \\
\hline 2019 & $\begin{array}{l}\text { Herhausen, D., Kleinlercher, K., } \\
\text { Verhoef, P.C., Emrich, O., } \\
\text { Rudolph, T. }\end{array}$ & $\begin{array}{l}\text { Loyalty Formation for Different } \\
\text { Customer Journey Segments }\end{array}$ & Journal of Retailing & [46] \\
\hline 2019 & Frasquet, M., Ieva, M., Ziliani, C. & $\begin{array}{l}\text { Understanding complaint channel } \\
\text { usage in multichannel retailing }\end{array}$ & $\begin{array}{l}\text { Journal of Retailing and } \\
\text { Consumer Services }\end{array}$ & {$[40]$} \\
\hline 2019 & Lee, Y., Cheon, H. & $\begin{array}{l}\text { A Study on the Factors Affecting the } \\
\text { User Intention of Omnichannel } \\
\text { Shopping Based on Information } \\
\text { Technology }\end{array}$ & Proceedings of ICEBA 2019 & [56] \\
\hline 2019 & $\begin{array}{l}\text { Orús, C., Gurrea, R., } \\
\text { Ibáñez-Sánchez, S. }\end{array}$ & $\begin{array}{l}\text { The impact of consumers' positive } \\
\text { online recommendations on the } \\
\text { omnichannel webrooming experience }\end{array}$ & Spanish Journal of Marketing & {$[43]$} \\
\hline
\end{tabular}


Table A1. Cont.

\begin{tabular}{|c|c|c|c|c|}
\hline Year & Authors & Title & Source & Reference \\
\hline 2020 & $\begin{array}{l}\text { Shi, S., Wang, Y., Chen, X., } \\
\text { Zhang, Q. }\end{array}$ & $\begin{array}{l}\text { Conceptualization of omnichannel } \\
\text { customer experience and its impact on } \\
\text { shopping intention: A mixed-method } \\
\text { approach }\end{array}$ & $\begin{array}{l}\text { International Journal of } \\
\text { Information Management }\end{array}$ & [58] \\
\hline 2020 & $\begin{array}{l}\text { Miquel-Romero, M.-J., Frasquet, } \\
\text { M., Molla-Descals, A. }\end{array}$ & $\begin{array}{l}\text { The role of the store in managing post } \\
\text { purchase complaints for omnichannel } \\
\text { shoppers }\end{array}$ & Journal of Business Research & {$[41]$} \\
\hline 2020 & Flavián, C., Gurrea, R., Orús C. & $\begin{array}{l}\text { Combining channels to make smart } \\
\text { purchases: The role of webrooming } \\
\text { and showrooming }\end{array}$ & $\begin{array}{l}\text { Journal of Retailing and } \\
\text { Consumer Services }\end{array}$ & [10] \\
\hline 2020 & $\begin{array}{l}\text { Shakir, Goraya M.A., Zhu J., } \\
\text { Akram, M.S., Mahmud, Akhter } \\
\text { Shareef, Malik, A., Bhatti Z.A. }\end{array}$ & $\begin{array}{l}\text { The impact of channel integration on } \\
\text { consumers' channel preferences: Do } \\
\text { showrooming and webrooming } \\
\text { behaviors matter? }\end{array}$ & $\begin{array}{l}\text { Journal of Retailing and } \\
\text { Consumer Services }\end{array}$ & [38] \\
\hline 2020 & Barwitz, N. & $\begin{array}{l}\text { The relevance of interaction choice: } \\
\text { Customer preferences and willingness } \\
\text { to pay }\end{array}$ & $\begin{array}{l}\text { Journal of Retailing and } \\
\text { Consumer Services }\end{array}$ & [33] \\
\hline
\end{tabular}

\section{References}

1. Sorescu, A.; Frambach, R.; Singh, J.; Rangaswamy, A.; Bridges, C. Innovations in Retail Business Models. J. Retail. 2011, 87, 3-16. [CrossRef]

2. Verhoef, P.C.; Kannan, P.K.; Inman, J.J. From Multi-Channel Retailing to Omni-Channel Retailing. Introduction to the Special Issue on Multi-Channel Retailing. J. Retail. 2015, 91, 174-181. [CrossRef]

3. Berman, B. Flatlined: Combatting the death of retail stores. Bus. Horiz. 2019, 62, 75-82. [CrossRef]

4. Huuhka, A.; Laaksonen, M.; Laaksonen, P. The evolution of new systemic forms in retailing and digital business. Contrib. Int. Bus. Acta Wasaensia 2014, 303, 239-249.

5. World Health Organization (WHO). Available online: https://www.who.int/emergencies/diseases/novel-coronavirus-2019/ (accessed on 28 December 2020).

6. Business Insider 2020. Available online: https:/ /www.businessinsider.com/shopifys-director-of-retail-helps-brick-and-mortarretailers-thrive-2020-10 (accessed on 24 December 2020).

7. Hübner, A.; Kuhn, H.; Wollenburg, J. Last mile fulfilment and distribution in omni-channel grocery retailing. A strategic planning framework. Int. J. Retail Distrib. Manag. 2016, 44, 228-247. [CrossRef]

8. Juaneda-Ayensa, E.; Mosquera, A.; Sierra Murillo, Y. Omnichannel Customer Behavior: Key Drivers of Technology Acceptance and Use and Their Effects on Purchase Intention. Front. Psychol. 2016, 7, 1117. [CrossRef]

9. Shen, X.-L.; Li, Y.-J.; Sun, Y.; Wang, N. Channel integration quality, perceived fluency and omnichannel service usage: The moderating roles of internal and external usage experience. Decis. Support Syst. 2018, 109, 61-73. [CrossRef]

10. Flavián, C.; Gurrea, R.; Orús, C. Combining channels to make smart purchases: The role of webrooming and showrooming. J. Retail. Consum. Serv. 2020, 52, 101923. [CrossRef]

11. Thaichon, P.; Phau, I.; Weaven, S. Moving from multi-channel to Omni-channel retailing: Special issue introduction. J. Retail. Consum. Serv. 2020. [CrossRef]

12. Lazaris, C.; Vrechopoulos, A. From Multichannel to "Omnichannel” Retailing: Review of the Literature and Calls for Research. In Proceedings of the 2nd International Conference on Contemporary Marketing Issues (ICCMI), Athens, Greece, 18-20 June 2014; p. 6.

13. Becker, L.; Jaakkola, E.L. Customer experience: Fundamental premises and implications for research. J. Acad. Mark. Sci. 2020, 48, 630-648. [CrossRef]

14. Bascur, C.; Rusu, C. Customer Experience in Retail: A Systematic Literature Review. Appl. Sci. 2020, 10, 7644. [CrossRef]

15. Lemon, K.; Verhoef, P. Understanding customer experience throughout the customer journey. J. Mark. 2016, 80, 69-96. [CrossRef]

16. Spychalska-Wojtkiewicz, M. The Relation between Sustainable Development Trends and Customer Value Management. Sustainability 2020, 12, 5496. [CrossRef]

17. Signori, P.; Gozzo, I.; Flint, D.; Milfeld, T.; Satinover Nichols, B. Sustainable Customer Experience: Bridging Theory and Practice, The Synergy of Business Theory and Practice. In Palgrave Studies in Cross-Disciplinary Business Research, in Association with EuroMed Academy of Business; Palgrave Macmillan: Cham, Switzerland, 2019.

18. Kitchenham, B.; Brereton, P. A systematic review of systematic review process research in software engineering. Inf. Softw. Technol. 2013, 55, 2049-2075. [CrossRef] 
19. Snyder, H. Literature review as a research methodology: An overview and guidelines. J. Bus. Res. 2019, 104, 333-339. [CrossRef]

20. Williams, R.I., Jr.; Clark, L.A.; Clark, W.R.; Raffo, D.M. Re-examining systematic literature review in management research: Additional benefits and execution protocols. Eur. Manag. J. 2020, in press. [CrossRef]

21. Paré, G.; Trudel, M.-C.; Jaana, M.; Kitsiou, S. Synthesizing information systems knowledge: A typology of literature reviews. Inf. Manag. 2015, 52, 183-199. [CrossRef]

22. Hossain, T.M.T.; Akter, S.; Kattiyapornpong, U.; Dwivedi, Y. Reconceptualizing Integration Quality Dynamics for Omnichannel Marketing. Ind. Mark. Manag. 2019, 87, 225-241. [CrossRef]

23. Picek, R.; Peras, D.; Mekovec, R. Opportunities and challenges of applying omnichannel approach to contact center. In Proceedings of the 2018 4th IEEE International Conference on Information Management (ICIM), Oxford, UK, 25-27 May 2018; pp. 231-235.

24. Popa, I.D.; Dabija, D.-C.; Grant, D.B. Exploring omnichannel retailing differences and preferences among consumer generations. In Applied Ethics for Entrepreneurial Success: Recommendations for the Developing World; Văduva, S., Fotea, I.Ş., Vaduva, L.P., Wilt, R., Eds.; Springer Proceedings in Business and Economics; Springer Nature Switzerland AG: Cham, Switzerland, 2019.

25. Cai, Y.-J.; Lo, C.K.Y. Omni-channel management in the new retailing era: A systematic review and future research agenda. Int. J. Prod. Econ. 2020, 229, 107729. [CrossRef]

26. Akter, S.; Hossain, M.H.; Lu, S.; Aditya, S.; Hossain, T.M.T.; Kattiyapornpong, U. Does Service Quality Perception in Omnichannel Retailing Matter? A Systematic Review and Agenda for Future Research. In Exploring Omnichannel Retailing; Springer Nature Switzerland: Cham, Switzerland, 2019; pp. 71-97.

27. Lehrer, C.; Jung, R. Channel integration towards omnichannel management: A literature review. In Proceedings of the Pacific Asia Conference on Information Systems (PACIS), Chiayi, Taiwan, 27 June-1 July 2016.

28. João, B.N.; Pastore, R. Research in omnichannel retail: A systematic review and quantitative content analysis. Braz. J. Mark. 2019, 18, 154-176. [CrossRef]

29. Braun, V.; Clarke, V. Using thematic analysis in psychology. Qual. Res. Psychol. 2006, 3, 77-101. [CrossRef]

30. Wang, Y.; Capon, N.; Wang, V.L.; Guo, C. Building industrial brand equity on resource advantage. Ind. Mark. Manag. 2018, 72, 4-16. [CrossRef]

31. Komulainen, H.; Makkonen, H. Customer experience in omni-channel banking services. J. Financ. Serv. Mark. 2018, 23, 190-199. [CrossRef]

32. Barwitz, N.; Maas, P. Understanding the Omnichannel Customer Journey: Determinants of Interaction Choice. J. Interact. Mark. 2018, 43, 116-133. [CrossRef]

33. Barwitz, N. The relevance of interaction choice: Customer preferences and willingness to pay. J. Retail. Consum. Serv. 2020, 53, 101953. [CrossRef]

34. Mahrous, A.A.; Hassan, S.S. Achieving Superior Customer Experience: An Investigation of Multichannel Choices in the Travel and Tourism Industry of an Emerging Market. J. Travel Res. 2017, 56, 1049-1064. [CrossRef]

35. Carnein, M.; Heuchert, M.; Homann, L.; Trautmann, H.; Vossen, G.; Becker, J.; Kraume, K. Towards Efficient and Informative Omni-Channel Customer Relationship Management. In Proceedings of the ER 2017 Workshops, Valencia, Spain, 6-9 November 2017; LNCS 10651. pp. 69-78.

36. Rebaque-Rivas, P.; Gil-Rodríguez, E. Adopting an Omnichannel Approach to Improve User Experience in Online Enrolment at an E-learning University. In Proceedings of the HCII 2019, Orlando, FL, USA, 26-31 July 2019; CCIS 1034. pp. 115-122.

37. Taylor, D.G.; Levin, M. Predicting mobile app usage for purchasing and information-sharing. Int. J. Retail aDistrib. Manag. 2014, 42, 759-774. [CrossRef]

38. Goraya, M.A.S.; Zhu, J.; Akram, M.S.; Shareef, M.A.; Malik, A.; Bhatti, Z.A. The impact of channel integration on consumers' channel preferences: Do showrooming and webrooming behaviors matter? J. Retail. Consum. Serv. 2020. [CrossRef]

39. Frasquet, M.; Miquel, M.J.; Mollá, A. Complaining at the Store or Through Social Media: The Influence of the Purchase Channel, Satisfaction, and Commitment. In Advances in National Brand and Private Label Marketing; Springer International Publishing: Cham, Switzerland, 2017.

40. Frasquet, M.; Ieva, M.; Ziliani, C. Understanding complaint channel usage in multichannel retailing. J. Retail. Consum. Serv. 2019, 47, 94-103. [CrossRef]

41. Miquel-Romero, M.-J.; Frasquet, M.; Molla-Descals, A. The role of the store in managing postpurchase complaints for omnichannel shoppers. J. Bus. Res. 2020, 109, 288-296. [CrossRef]

42. Rosenmayer, A.; McQuilken, L.; Robertson, N.; Ogden, S. Omni-channel service failures and recoveries: Refined typologies using Facebook complaints. J. Serv. Mark. 2018, 32, 269-285. [CrossRef]

43. Peltola, S.; Vinio, H.; Nieminen, M. Key factors in developing omnichannel customer experience with finnish retailers. In HCIB; Springer International Publishing: Cham, Switzerland, 2015; pp. 335-346.

44. Orús, C.; Gurrea, R.; Ibáñez-Sánchez, S. The impact of consumer's positive online recommendations on the omnichannel webrooming experience. Span. J. Mark. 2019. ESIC ahead-of-print.

45. Lee, S.; Lim, T.-S. Retailer's Innovative Differentiation Method Based on Customer Experience: Focusing Mediating Effect of Omni-channel Shopper Type. Qual. Innov. Prosper./Kval. Inovácia Prosper. 2017, 21, 37-51. [CrossRef]

46. Herhausen, D.; Kleinlercher, K.; Verhoef, P.T.; Emrich, O.; Rudolph, T. Loyalty formation for different customer journey segments. J. Retail. 2019, 95, 9-29. [CrossRef] 
47. Xiao, L.; Guo, Z.; D’Ambra, J. Benefit-based O2O commerce segmentation: A means-end chain approach. Electron. Commer. Res. 2018, 19, 409-449. [CrossRef]

48. Ervasti, M.; Isomursu, M.; Mäkelä, S.-M. Enriching Everyday Experience with a Digital Service: Case Study in Rural Retail Store. In Proceedings of the BLED 2014 Proceedings, Bled, Slovenia, 1-5 June 2014; p. 20.

49. Demko-Rihter, J.; ter Halle, I. Revival of high street retailing-The added value of shopping apps. Amfiteatru Econ. 2015, 17, 632-645.

50. Parise, S.; Guinan, P.J.; Kafka, R. Solving the crisis of immediacy: How digital technology can transform the customer experience. Bus. Horiz. 2016, 59, 411-420. [CrossRef]

51. Zagel, C.; Wright, O.; Winzar, H. Using Smartphones for Information Retrieval in Omnichannel Scenarios-Assessing the Effectiveness of Technological Triggers. In Proceedings of the AHFE 2016 International Conference on the Human Side of Service Engineering, Walt Disney World, FL, USA, 27-31 July 2016.

52. Belghiti, A.C.; Lemoine, J.-F.; Badot, O. The Phygital Shopping Experience: An Attempt to Conceptualization and Empirical Investigation. In Marketing Transformation: Marketing Practice in an Ever Changing World, Developments in Marketing Science, Proceedings of the Academy of Marketing Science, New Orleans, LA, USA 23-25 May 2018; Springer International Publishing: Cham, Switzerland, 2018.

53. Saghiri, S.; Wilding, R.; Mena, C.; Bourlakis, M. Toward a three-dimensional framework for omni-channel. J. Bus. Res. 2017, 77, 53-67. [CrossRef]

54. Bernon, M.; Cullen, J.; Gorst, J. Online retail returns management. Integration within an omni-channel distribution context. Int. J. Phys. Distrib. Logist. Manag. 2015, 46, 584-605. [CrossRef]

55. Murfield, M.; Boone, C.; Rutner, P.; Thomas, R. Investigating logistics service quality in omni-channel retailing. Int. J. Phys. Distrib. Logist. Manag. 2017, 47, 263-296. [CrossRef]

56. Lee, Y.; Cheon, H. A Study of the Factors Affecting the User Intention of Omnichannel Shopping Based on Information Technology. In Proceedings of the ICEBA 2019, Bangkok, Thailand, 25-28 February 2019; pp. 20-24.

57. Kaczorowska-Spychalska, D. Consumer perspective of omnichannel commerce. Management 2017, 21, 95-108. [CrossRef]

58. Shi, S.; Wang, Y.; Chen, Z.; Zhang, Q. Conceptualization of omnichannel customer experience and its impact on shopping intention: A mixed-method approach. Int. J. Inf. Manag. 2020, 50, 325-336. [CrossRef]

59. Herhausen, D.; Binder, J.; Schoegel, M.; Herrmann, A. Integrating Bricks with Clicks: Retailer-Level and Channel-Level Outcomes of Online-Offline Channel Integration. J. Retail. 2015, 91, 309-325. [CrossRef]

60. Kumar, V.; Rajan, B.; Gupta, S.; Dalla Pozza, I. Customer engagement in service. J. Acad. Mark. Sci. 2017, 47, 138-160. [CrossRef]

61. Zhang, M.; Ren, C.; Wang, G.A.; He, Z. The impact of channel integration on consumer responses in omnichannel retailing: The mediating effect of consumer empowerment. Electron. Commer. Res. Appl. 2018, 28, 181-193. [CrossRef]

62. Huré, E.; Picot-Coupey, K.; Ackermannn, C.-L. Understanding omni-channel shopping value: A mixed-method study. J. Retail. Consum. Serv. 2017, 39, 314-330. [CrossRef]

63. Gioia, D.A.; Pitre, E. Multiparadigm perspectives on theory building. Acad. Manag. Rev. 1990, 15, 584-602. [CrossRef]

64. Lewis, M.W.; Grimes, A.J. Metatriangulation: Building theory from multiple paradigms. Acad. Manag. Rev. 1999, 24, 672-690. [CrossRef]

65. Okhuysen, G.; Bonardi, J. The challenges of building theory by combining lenses. Acad. Manag. Rev. 2011, 36, 6-11. [CrossRef]

66. Koul, S.; Eydgahi, A. A systematic review of technology adoption frameworks and their applications. J. Technol. Manag. Innov. 2017, 12, 106-113. [CrossRef]

67. Ajzen, I. From intentions to actions: A theory of planned behavior. In Action Control: From Cognition to Behavior; Kuhl, J., Beckmann, J., Eds.; Springer: Berlin/Heidelberg, Germany; New York, NY, USA, 1985; pp. 11-39.

68. $\mathrm{Xu}, \mathrm{X} . ;$ Jackson, J. Examining customer channel selection intention in the omni-channel retail environment. Int. J. Prod. Econ. 2019, 208, 434-445. [CrossRef]

69. Davis, F. A Technology Acceptance Model for Empirically Testing New End-User Information Systems: Theory and Results. Ph.D. Thesis, Massachusetts Institute of Technology, Cambridge, MA, USA, 1985.

70. Wetzlinger, W.; Auinger, A.; Kindermann, H.; Schöenberger, W. Acceptance of Personalization in Omnichannel Retailing, Conference. In Proceedings of the International Conference on HCI in Business, Government, and Organizations, Vancouver, BC, Canada, 9-14 July 2017.

71. De Silva, S.C.; Martins, C.C.; de Sousa, J.M. Omnichannel approach: Factors affecting customer experience. J. Mark. Channels 2019, 25, 73-84. [CrossRef]

72. Vroom, V.H. Work and Motivation; John Wiley \& Sons, Inc: New York, NY, USA, 1964; p. 331.

73. Quiggin, J. A theory of anticipated utility. J. Econ. Behav. Organ. 1982, 3, 323-343. [CrossRef]

74. Kim, E.; Park, M.-C.; Lee, J. Determinants of the intention to use Buy-Online, Pickup In-Store (BOPS): The moderating effects of situational factors and product type. Telemat. Inform. 2017, 34, 1721-1735. [CrossRef]

75. Rogers, E.M. Diffusion of Innovations; Free Press: New York, NY, USA, 1962.

76. Venkatesh, V.; Morris, M.G.; Davis, G.B.; Davis, F.D. User Acceptance of Information Technology: Toward a Unified View. MIS Q. 2003, 27, 425-478. [CrossRef]

77. Pagani, M.; Racat, M.; Hofacker, C.F. Adding Voice to the Omnichannel and How that Affects Brand Trust. J. Interact. Mark. 2019, 48, 89-105. [CrossRef] 
78. Kim, R.; Matsui, T.; Park, J.; Okutani, T. Perceived Consumer Value of Omni-Channel Service Attributes in Japan and Korea. Inz. Ekon. Eng. Econ. 2019, 30, 621-630. [CrossRef]

79. Brereton, P.; Kitchenham, B.; Budgen, D.; Turner, M.; Khalil, M. Lessons from applying the systematic literature review process within the software engineering domain. J. Syst. Softw. 2007, 80, 571-583. [CrossRef]

80. Hajdas, M.; Radomska, J.; Silva, S.C. The omni-channel approach: A utopia for companies? J. Retail. Consum. Serv. 2020. [CrossRef]

81. Li, Y.; Liu, H.; Lim, E.T.K.; Goh, J.M.; Yang, F.; Lee, M.K.O. Customer's reaction to cross-channel integration in omnichannel retailing: The mediating roles of retailer uncertainty, identity attractiveness, and switching costs. Decis. Support Syst. 2018, 109, 50-60. [CrossRef]

82. Wunderman-Thompson. The Future Shopper Report. 2020. Available online: https://insights.wundermanthompsoncommerce. com/the-future-shopper-2020 (accessed on 18 October 2020).

83. Maier, E.; Wieringa, J. Acquiring customers through online marketplaces? The effect of marketplace sales on sales in a retailer's own channels. Int. J. Res. Mark. 2020, in press. [CrossRef]

84. Dhebar, A. Toward a compelling customer touchpoint architecture. Bus. Horiz. 2013, 56, 199-205. [CrossRef]

85. Payne, L.M.; Peltier, J.W.; Barger, V.A. Omni-channel marketing, integrated marketing communications, and consumer engagement: A research agenda. J. Res. Interact. Mark. 2017, 11, 185-197. [CrossRef]

86. Anastasiei, B.; Dospinescu, N. Paid Product Reviews in Social Media-Are They Effective? In Proceedings of the 34th International Business Information Management Association Conference, Vision 2025: Education Excellence and Management of Innovations through Sustainable Economic Competitive Advantage, Madrid, Spain, 13-14 November 2019.

87. Anastasiei, B.; Dospinescu, N. A model of the relationships between the Big Five personality traits and the motivations to deliver word-of-mouth online. Psihologija 2018, 51, 215-227. [CrossRef]

88. Huete-Alcocer, N. Literature Review of Word of Mouth and Electronic Word of Mouth: Implications for Consumer Behavior. Front. Psychol. 2017, 8, 1256. [CrossRef]

89. Garrett, A.; Straker, K.; Wrigley, C. Digital channels for building collaborative consumption communities. J. Res. Interact. Mark. 2017, 11, 160-184. [CrossRef]

90. Pascoe, M.; Wright, O.; Winzar, H. Using best-words scaling to reveal perceived relative importance of website attributes. Asia Pac. J. Mark. 2017, 29, 393-408. [CrossRef]

91. Rajan, C.R.; Swaminathan, T.N.; Pavithra, M.R. Key Drivers of Purchase Intent by Indian Consumers in Omni-Channel Shopping. Indian J. Mark. 2017, 47, 7-20. [CrossRef]

92. Mosquera, A.; Olarte-Pascual, C.; Ayensa, E.J.; Murrillo, Y.S. The role of technology in an omnichannel physical store. Assessing the moderating effect of gender. Span. J. Mark. 2017, 22, 63-82.

93. Siqueira, J.R., Jr.; Peña, N.G.; ter Horst, E.; Molina, G. Spreading the Word: How Customer Experience in a Traditional Retail Setting Influences Consumer Traditional and Electronic Word-of-mouth Intention. Electron. Commer. Res. Appl. 2019, $37,100870$. [CrossRef]

94. Lee, Z.W.Y.; Chan, T.K.H.; Yee-Loong Chong, A.; Thadani, D.R. Customer engagement through omnichannel retailing: The effects of channel integration quality. Ind. Mark. Manag. 2019, 77, 90-101. [CrossRef] 